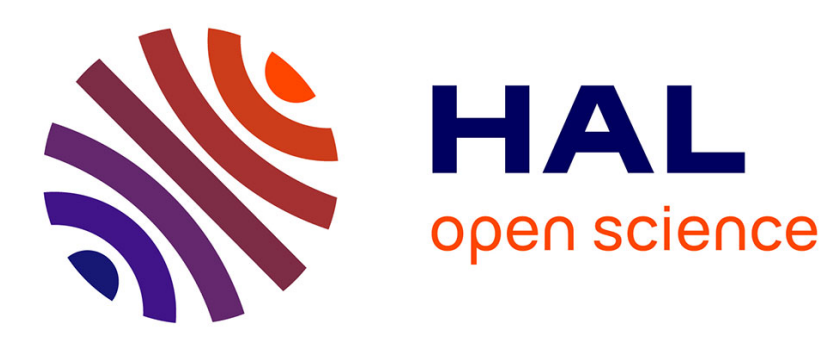

\title{
Defining zooplankton habitats in the Gulf of Lion (NW Mediterranean Sea) using size structure and environmental conditions
}

Boris Espinasse, Francois Carlotti, M. Zhou, Jean Luc Devenon

\section{To cite this version:}

Boris Espinasse, Francois Carlotti, M. Zhou, Jean Luc Devenon. Defining zooplankton habitats in the Gulf of Lion (NW Mediterranean Sea) using size structure and environmental conditions. Marine Ecology Progress Series, 2014, 506, pp.31-46. 10.3354/meps10803 . hal-01238217

\section{HAL Id: hal-01238217 https://hal.science/hal-01238217}

Submitted on 10 May 2021

HAL is a multi-disciplinary open access archive for the deposit and dissemination of scientific research documents, whether they are published or not. The documents may come from teaching and research institutions in France or abroad, or from public or private research centers.
L'archive ouverte pluridisciplinaire HAL, est destinée au dépôt et à la diffusion de documents scientifiques de niveau recherche, publiés ou non, émanant des établissements d'enseignement et de recherche français ou étrangers, des laboratoires publics ou privés. 


\title{
Defining zooplankton habitats in the Gulf of Lion (NW Mediterranean Sea) using size structure and environmental conditions
}

\author{
B. Espinasse ${ }^{1,2, *}$, F. Carlotti ${ }^{1,2}$, M. Zhou ${ }^{3}$, J. L. Devenon ${ }^{1,2}$ \\ ${ }^{1}$ Aix Marseille Université, CNRS/INSU, IRD, Mediterranean Institute of Oceanography (MIO), UM 110, Marseille, France \\ ${ }^{2}$ Université du Sud Toulon-Var, CNRS/INSU, IRD, Mediterranean Institute of Oceanography (MIO), UM 110, La Garde, France \\ ${ }^{3}$ Department of Environmental, Earth and Ocean Sciences, University of Massachusetts Boston, 100 Morrissey Blvd, Boston, \\ Massachusetts 02125, USA
}

\begin{abstract}
The size structure of zooplankton communities in the Gulf of Lion, NW Mediterranean Sea, was studied in May 2010 and January 2011. The integrated physical and biological measurements provided a 3D view with high spatial resolution of the physical and biological variables and their correlations over the whole gulf. The effects of physical processes such as freshwater input, coastal upwelling, and water column mixing by winds on phytoplankton and zooplankton distributions were analyzed using these data. During the winter, strong northerly winds mixed the water column, and the vertical distributions of biological variables were uniform over most of the gulf while there were local hot spots with high chlorophyll $a(\mathrm{chl} a$ ) concentrations in front of the Rhône mouths and in coastal areas. During the spring, light winds and water column stratification resulted in less vertical mixing, and the Rhône River freshwater plume spread over a large part of the gulf. The nutrients delivered by the freshwater input encouraged high primary production in the surface layer. In the pycnocline, a thin layer of high particle concentration was associated with these high phytoplankton biomasses. Three habitats were distinguished based on statistical analysis performed on biological and physical variables: (1) the coastal area characterized by shallow waters, high chl a concentrations, and a steep slope of the normalized biomass size spectrum (NBSS); (2) the area affected by the Rhône with high stratification and flat NBSS slope; and (3) the continental shelf with a deep mixed layer, relatively low particle concentrations, and moderate NBSS slope. Defining habitat is a relevant approach to designing new zooplankton sampling strategies, validating distribution models and including the zooplankton compartment in trophodynamic studies.
\end{abstract}

KEY WORDS: Plankton dynamics $\cdot$ Size spectra $\cdot$ Freshwater plume $\cdot$ Stratification $\cdot$ Coastal ecosystems · River Rhône

\section{INTRODUCTION}

Continental margins are generally highly productive areas compared to the open sea and provide the main spawning habitats for small pelagic fishes (Palomera et al. 2007, Planque et al. 2007, Bellido et al. 2008, Nicolle et al. 2009). Shallow waters, stronger currents, river discharges, and wind-driven upwelling cause strong variations in physical struc- tures, resulting in a variety of hydrological patterns (Yanagi 2000). Physical processes have direct effects on the production of the first trophic levels by mixing different water masses and bringing nutrients from terrestrial runoff and coastal upwelling. To understand how these environmental conditions affect zooplankton distributions at the mesoscale, physical and biological variables must to be measured simultaneously at a sufficiently high resolution to detect fine 
structures in the water column (Labat et al. 2009, Möller et al. 2012, Ohman et al. 2012). The data from high-resolution measurements can be used to determine zooplankton habitats with specific hydrological and biological features. Recent advances in in situ optical and acoustic sensors have made such highresolution measurements of physical and biological variables possible (Mikkelsen \& Pejrup 2001, Davis et al. 2004, Jiang et al. 2007, Picheral et al. 2010, Powell \& Ohman 2012). The laser optical plankton counter (LOPC) can be used to measure the size spectrum of zooplankton communities (Herman et al. 2004) and can also be coupled with other sensors to monitor simultaneous changes in the physical and biological variables along the water column. In conjunction with net tows to establish ground truth, this size structure approach provides important information on the functioning of marine ecosystems. The characteristics of the size spectrum have been successfully used in several studies as an indicator for the dynamics of plankton communities (Matsuno et al. 2012, Tarling et al. 2012, Schultes et al. 2013, Basedow et al. 2014). Size-based mathematical models have been developed and can be used to determine the characteristics of plankton communities and to quantify the efficiency of energy transfer between trophic levels (Zhou 2006, Andersen et al. 2009). Sizes of zooplankton organisms also play an important role in predator-prey interactions, espe-

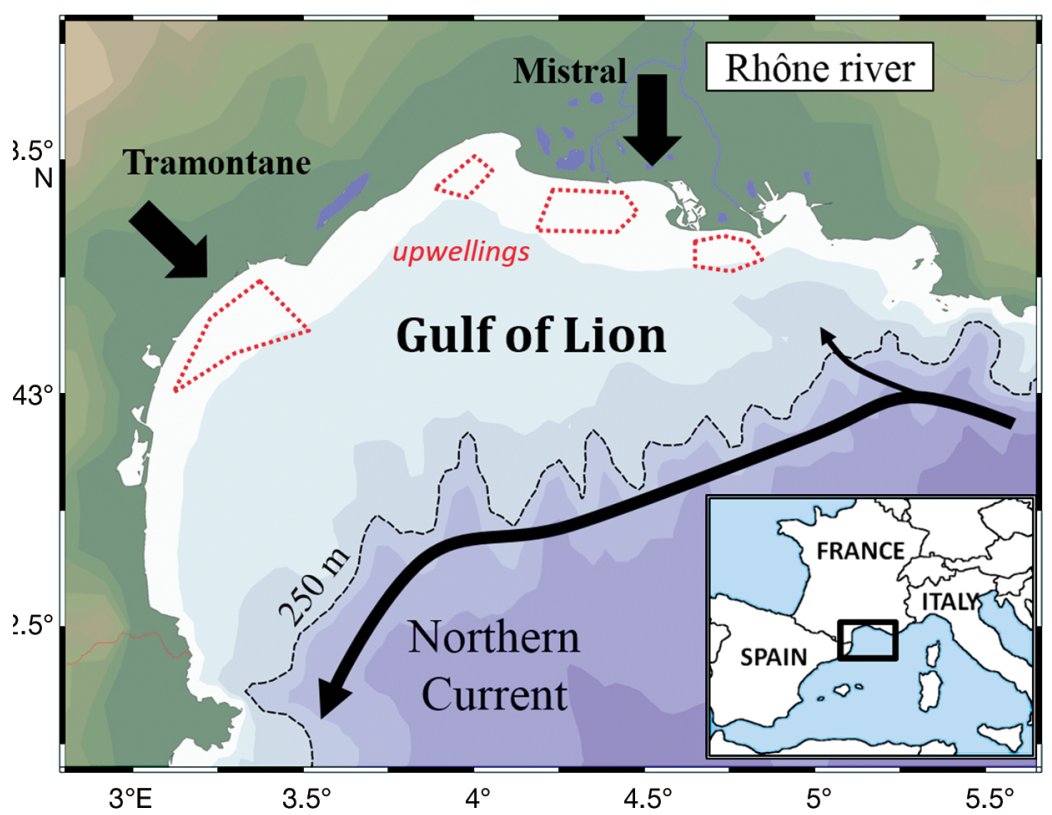

Fig. 1. Schematic representation of the main hydroclimatic phenomena that interact with the physical features in the Gulf of Lion. Tramontane and Mistral are frequently occurring strong winds that create coastal upwellings and drive the dispersion and dilution of the Rhône River plume cially in the survival of fish larvae (Plounevez \& Champalbert 2000, Costalago et al. 2012, Nikolioudakis et al. 2012). Although the concept of habitat is widely used and well defined for the study of fish (Bellido et al. 2008, Giannoulaki et al. 2011, Tugores et al. 2011, Salas-Berrios et al. 2013), only a few studies have used this concept for zooplankton. The species-based approach used to study fish is difficult to transpose to the zooplankton compartment, especially in tropical and temperate regions with high biodiversity. Zooplankton habitats are therefore generally defined as function of the environmental conditions that create a specific assemblage of species characterized by taxonomic composition (Schulz et al. 2012, Sano et al. 2013) or size structure features (Matsuno et al. 2012). In this study, we characterized zooplankton communities by their abundances and size structures rather than by taxonomic composition. The term 'habitat' is used to refer to geographical areas where there are statistically meaningful relationships between the environmental conditions and zooplankton community variables.

The Gulf of Lion in the northwestern (NW) Mediterranean Sea has a large continental shelf up to $80 \mathrm{~km}$ wide (Fig. 1). Several rivers, in particular the Rhône River, flow into the Gulf of Lion carrying freshwater, terrestrial particles, and nutrients. The Northern Current (NC) flows southwestwards along the continental slope and sometimes intrudes onto the shelf, bringing oligotrophic waters into the gulf. Strong winds such as the Mistral and Tramontane occur frequently, creating coastal upwellings and driving the dispersion and dilution of the Rhône River plume. The hydrography of the Gulf of Lion is well documented (Millot 1990, Broche et al. 1998, Petrenko et al. 2005) and simulated by several physical models (Estournel et al. 2003, André et al. 2005, Rubio et al. 2009). The MARS3D hydrodynamic model simulates circulation in the NW Mediterranean and resolves the coastal dynamics. The effects of the Rhône River plume on biological processes have been described in many studies dealing with nutrient inputs, phytoplankton growth, and zooplankton grazing and behavior (Gaudy et al. 1990, Pagano et al. 1993, Pujo-Pay et al. 2006, Diaz et al. 2008). However, very few studies have been undertaken for the area 
spanning coastal runoff to the $\mathrm{NC}$ in the past $25 \mathrm{yr}$ (Kouwenberg 1994, Gaudy et al. 2003), and these do not provide an overall view of the distributions. Furthermore, only 1 study focused on the size structure of zooplankton communities (Riandey 2005). Considerable efforts have been made to study trophic dynamics and effects of physical processes at different scales in the Gulf of Lion (Raimbault \& Durrieu de Madron 2003, Bănaru et al. 2013), but, despite the key position of the zooplankton compartment in the food web, no studies have used a specific sampling strategy to determine zooplankton dynamics.

Two surveys were conducted in May 2010 and January 2011 over the entire Gulf of Lion to produce 3D maps of zooplankton distributions and environmental conditions simultaneously at a synoptic scale. The aims of this study were (1) to define spatial zooplankton habitats in relation to environmental conditions, (2) to identify the main processes shaping the habitats, and (3) to suggest a method suitable for coastal marine ecosystem monitoring and management in the future.

\section{MATERIALS AND METHODS}

\section{Data collection and sampling}

Two surveys were conducted on board the RV 'Téthys II': from 25 April to 2 May 2010 (COSTEAU 4) and from 23 to 27 January 2011 (COSTEAU 6). Six transects from the coast to the open sea were surveyed with up to 15 sampling stations at regular intervals of 2.5 nautical miles (Table 1). All sampling operations were carried out during the day from the bottom, or a maximum depth of $200 \mathrm{~m}$ for offshore stations, to the surface using a Seabird 911 CTD

Table 1. Dates and numbers of stations for each transect during 2 sampling campaigns in the NW Mediterranean Sea: COSTEAU 4 (2010) and COSTEAU 6 (2011); 'trans.' stations were between 2 transects. Positions of the stations are shown in Fig. 3a

\begin{tabular}{|c|c|c|c|c|}
\hline \multirow{2}{*}{$\begin{array}{l}\text { Tran- } \\
\text { sect }\end{array}$} & \multicolumn{2}{|c|}{- COSTEAU $4-$} & \multicolumn{2}{|c|}{- COSTEAU $6-$} \\
\hline & $\begin{array}{c}\text { Date } \\
(\mathrm{dd} / \mathrm{mm})\end{array}$ & $\begin{array}{c}\text { No. of } \\
\text { stations }\end{array}$ & $\begin{array}{c}\text { Date } \\
(\mathrm{dd} / \mathrm{mm})\end{array}$ & $\begin{array}{c}\text { No. of } \\
\text { stations }\end{array}$ \\
\hline A & $27 / 04$ & 11 (+ 2 trans.) & $23 / 01$ & 13 (+ 1 trans.) \\
\hline B & $28 / 04$ & 14 & $24 / 01$ & 7 \\
\hline $\mathrm{C}$ & $29 / 04$ & 12 & $25 / 01$ & $15(+2$ trans. $)$ \\
\hline $\mathrm{D}$ & $30 / 04$ & 14 (+ 1 trans.) & 26/01 & 14 (+ 1 trans. $)$ \\
\hline $\mathrm{E}$ & 01/05 & 6 & $27 / 01$ & 15 \\
\hline $\mathrm{F}$ & $02 / 05$ & 6 & & \\
\hline
\end{tabular}

(Sea-Bird Electronics), an Aqua Tracka 3 fluorometer (Chelsea Technologies Group), and a LOPC (Herman et al. 2004) mounted on a 12-bottle Rosette water sampler. Water samples were collected at a range of depths and immediately filtered using GF/F filters. In the laboratory, chlorophyll a ( $\mathrm{chl} a$ ) was extracted in an acetone solution as described by Aminot \& Kérouel (2004). The regression between in situ-measured fluorescence (fluo) and laboratory-measured chl $a$ were determined as chl $a=1.64 \times$ fluo $\left(\mathrm{R}^{2}=0.77\right.$, $\mathrm{n}=202)$ for COSTEAU 4 and chl $a=5.43 \times$ fluo $\left(\mathrm{R}^{2}=\right.$ $0.83, \mathrm{n}=201$ ) for COSTEAU 6 . Wind data were obtained from the maritime meteorological station and weather forecast model Aladin from Météo-France.

The recently developed LOPC has already been used in several studies (Finlay et al. 2007, Checkley et al. 2008, Gaardsted et al. 2010, Ohman et al. 2012, Basedow et al. 2013). The high acquisition rate of the LOPC, and the simultaneous measurements of other variables, provides the fine spatial resolution mapping necessary for understanding the interactions between environmental conditions and zooplankton communities. The LOPC was coupled to a data logger and a micro-CTD to measure the vertical distribution of the size spectrum and abundance of particles (zooplankton and suspended particulate matter) from $100 \mu \mathrm{m}$ to $1 \mathrm{~cm}$ equivalent spherical diameter (ESD; Herman et al. 2004). The LOPC has a flow-through tunnel with an open area of $7 \times 7 \mathrm{~cm}$ and measures the attenuation of the light intensity caused by particles passing through the tunnel and crossing at the laser beam. The digital size of the particles is inferred from the changes in intensity and is converted to the ESD. The data were processed using a program developed on MATLAB software (Mathworks). Like other laser-based sensors, the LOPC does not distinguish between organisms and suspended particulate matter (SPM). However, recent studies have described the development of new theoretical ways for separating living and non-living particles, based on the lognormal distribution expected for particle spectra (Petrik et al. 2013), and using an opacity index to separate zooplankton organisms from SPM for particles over $1.5 \mathrm{~mm}$ ESD (Checkley et al. 2008). Unfortunately, these methods were not suitable for this study owing to the low concentrations of organisms over 2 $\mathrm{mm}$ ESD in the Mediterranean Sea and the small volume of water analyzed at each cast.

Spatial and transect maps were generated using Ocean Data View (Schlitzer 2014) with the embedded gridding software DIVA (Troupin et al. 2012). Data from a hull-mounted acoustic Doppler current profiler (ADCP, $150 \mathrm{kHz}$, RD Instruments) and simu- 
lations from the MARS-3D hydrographic model (André et al. 2005) were used to assess the stability of the physical structures during the surveys.

\section{Habitat mapping}

The methodology used to define habitats followed a sequence of operations: (1) selection of a limited number of measured or calculated variables; (2) principal component analysis (PCA) of these variables; (3) cluster analysis of the stations characterized by their coordinates on the principal components (PCs); (4) definition of the number of clusters using an objective measure of partitioning efficiency.

The first step characterized each station using a limited set of variables representing hydrological and biological features and including vertical information (Table 2). Several sets of variables were tested with the objective of balancing them between physical and biological variables. Physical variables were selected to be representative of all the physical processes occurring in the gulf. Five variables were selected: sea surface temperature and salinity, mixed layer depth, stratification index, and potential density at the bottom. The stratification index was calculated using the Brunt-Väisälä frequency $(\mathrm{N})$. Each station where at some depths $\mathrm{N}^{2}$ was higher than $10^{-3} \mathrm{~s}^{-2}$ was considered to have a pronounced pycnocline. To calculate the intensity of the pycnocline, a density profile model $\left(\rho_{\bmod }\right)$ was defined using the following function:

$$
\rho_{\text {mod }}=\rho_{h 0}+\frac{\Delta \rho_{h}}{2}\left[1+\tanh \alpha\left(z-z_{0}\right)\right]
$$

where $\rho_{h 0}$ (density at top of section), $\Delta \rho_{h}$ (density change over the section), and $z_{0}$ (absolute depth at inflexion point) were evaluated directly on a profile section centered on the pycnocline. Parameter $\alpha$ was estimated using least-squares minimization of the difference between the modeled density profile and the observed profile. Differentiating this equation related to $d z$ gives:

$$
\frac{\mathrm{d} \rho_{\mathrm{mod}}}{\mathrm{d} z}=\frac{\Delta \rho_{h}}{2} \alpha\left[1-\tanh ^{2} \alpha\left(z-z_{0}\right)\right]
$$

The stratification index $d \rho_{\bmod } / \mathrm{d} z$ is the value of the slope at the inflexion point, where $z=z_{0}$ :

$$
\frac{\mathrm{d} \rho_{\bmod }}{\mathrm{d} z}=\frac{\Delta \rho_{h}}{2} \alpha
$$

The depth at which $\mathrm{N}^{2}$ was greater than $0.2 \times$ $10^{-3} \mathrm{~s}^{-2}$ was taken to define the mixed layer depth. In
Table 2. Physical and biological variables and indices. SST: sea surface temperature; SSS: sea surface salinity; NBSS: normalized biomass size spectrum

\begin{tabular}{|lll|}
\hline Variable & Notation & Unit \\
\hline Physical conditions & & \\
SST & Temp_0 & ${ }^{\circ} \mathrm{C}$ \\
SSS & Sal_0 & \\
Bottom potential density & Rho_b & $\mathrm{kg} \mathrm{m}^{-3}$ \\
Mixed layer depth & $Z_{\text {OML }}$ & $\mathrm{m}$ \\
Stratification index & Rho_grad & \\
Biological conditions & & \\
Integrated chlorophyll a & Chla_int & $\mathrm{mg} \mathrm{m}^{-3}$ \\
concentration & & \\
Integrated particle abundance & & ${\mathrm{no} . \mathrm{m}^{-3}}$ \\
$0.1-0.3 \mathrm{~mm}$ & $X_{0.1-0.3 \mathrm{~mm}}$ & \\
$0.3-0.5 \mathrm{~mm}$ & $X_{0.3-0.5 \mathrm{~mm}}$ & \\
$>0.5 \mathrm{~mm}$ & $X_{0.5 \mathrm{~mm}}$ & \\
Slope of NBSS & & \\
\hline
\end{tabular}

addition to the chl a concentration, biological variables were selected to characterize zooplankton communities. The selection was based on the type of data obtained by the optical sensors used. The variables selected were the abundance of 3 particle size classes integrated along the water column and the slope of the normalized biomass size spectrum (NBSS).

The next step was to perform a PCA on the data set constructed from all of these variables. This step identified any significant correlation between the variables, showed which variables influenced the variability between stations, and reduced the number of variables to the 3 principal components. Outliers were defined arbitrarily by calculating the Mahalanobis distance (MD) for the distributions of stations, and setting a threshold of $\mathrm{MD}^{2}=50$, which resulted in 2 outliers (out of 165 stations). Although outliers were excluded from the data set used for the calculation, their coordinates on the PC axes were calculated. The PCA was performed separately on the data sets for each survey in order to avoid the cluster definition being biased by the variability in the variables between the 2 surveys.

A cluster analysis was then performed on the stations characterized by the PCs. The Davies-Bouldin (DB) index, which is an objective measure of partitioning efficiency, provided the optimal number of groups defined by clustering (Davies \& Bouldin 1979). The number 3 was selected since it gave one of the lowest DB index values for both the COSTEAU 4 and the COSTEAU 6 surveys (Fig. 2), making it possible to compare the distribution of the habitats between the 2 periods. Furthermore, although the DB index was relatively low for 7 clusters for the May 


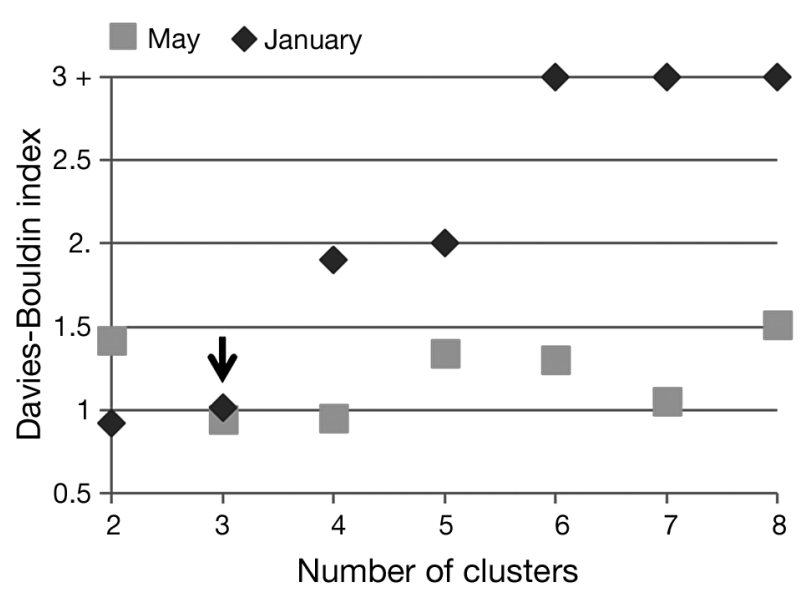

Fig. 2. Davies-Bouldin index of partitioning efficiency as a function of number of clusters. Lower index values indicate better partitioning. The black arrow shows the number of clusters selected

data, it was preferable to have a limited number of habitats for summarizing the information and be able to explain the differences between each region. All statistical tests were carried out using the dudi.pca, kmeans, and index.DB functions of the 'R' free statistical software (R Development Core Team 2014).

\section{Size spectrum}

Normalized biomass size spectra (NBSS) were calculated as described by Herman \& Harvey (2006). Using logarithmic bins provided high resolution for small sizes and avoided empty classes for large sizes. The biomass within each size class was divided by the class width to normalize the biomass size spectrum. Finally, each NBBS was divided by the corresponding volume of filtered water. A linear regression performed on the NBSS provided the slope and the $y$-intercept of the NBSS. NBSS slopes were calculated from the third class $(120 \mu \mathrm{m}$ ESD) to the first empty class in the spectrum. The NBSS slope is linked to the community assimilation efficiency across the size spectrum and the number of trophic levels (Gaedke 1993, Gilabert 2001, Zhou 2006).

\section{RESULTS}

\section{Weather conditions and river discharges}

During the January survey, strong northerly winds blew regularly and played an important role in homogenizing and cooling the water column. The Rhône River discharge was up to $3410 \mathrm{~m}^{3} \mathrm{~s}^{-1} 2 \mathrm{wk}$ before the survey, well above the annual average (1721 $\mathrm{m}^{3} \mathrm{~s}^{-1}$; Ludwig et al. 2009) but below extreme flash flood events $\left(>5000 \mathrm{~m}^{3} \mathrm{~s}^{-1}\right)$. In May, the winds were light with frequent changes in direction, and the Rhône River discharge was slightly below the annual average, down to $1343 \mathrm{~m}^{3} \mathrm{~s}^{-1}$ during the $2 \mathrm{wk}$ preceding the survey.

\section{Stability of the physical structures}

The stability of the physical structures during the survey ( $6 \mathrm{~d}$ for COSTEAU 4 and $5 \mathrm{~d}$ for COSTEAU 6 ) was investigated using ADCP data (not included in this paper) and simulations from the hydrodynamic circulation model MARS-3D. The predictions from the MARS-3D model gave a better, more detailed insight of spatial and temporal scales of variability. The wind conditions and river flows, which are the main factors of non-stationarity over short time scales in the Gulf of Lion, were constant during both surveys, resulting in the model predicting nearly stable physical structures. This was in agreement with the low values of currents inferred from ADCP data. We therefore assumed that the spatial distributions were quasi-stationary and good representatives of their mean values over the time scales of the surveys.

\section{Hydrological structures}

In January 2011, the effect of the Rhône was limited to the area near the coast, easily identifiable with colder, low salinity surface waters compared to the marine waters (temperature, $T<12^{\circ} \mathrm{C}$ and salinity, $S<35$; Fig. 3a). The Rhône divides into 2 branches $50 \mathrm{~km}$ upstream of the coast, which explains the presence of 2 plumes: 1 to the east associated with the Great Rhône and 1 to the west associated with the Little Rhône. Along the continental slope, $S>38$ and high temperature $\left(>13^{\circ} \mathrm{C}\right)$ revealed the presence of the NC. Cooling processes take place in the western part of the Gulf of Lion in the shallowest waters $\left(<11.5^{\circ} \mathrm{C}\right)$. The slight decrease in salinity was associated with the mouths of several small rivers. Cooling processes were found along Transect $\mathrm{D}$ with a tongue of cold water $\left(<11.5^{\circ} \mathrm{C}\right)$ in the bottom layer (Fig. $\left.3 \mathrm{~b}\right)$. A front separating the continental shelf waters from the NC waters was also clearly identifiable $(S>38$ and $T>13^{\circ} \mathrm{C}$ ), $50 \mathrm{~km}$ away from the coast. The Rhône River plume was a very thin surface layer near the coast (less than $3 \mathrm{~m}$ thick) and diluted vertically towards the open sea. 
a

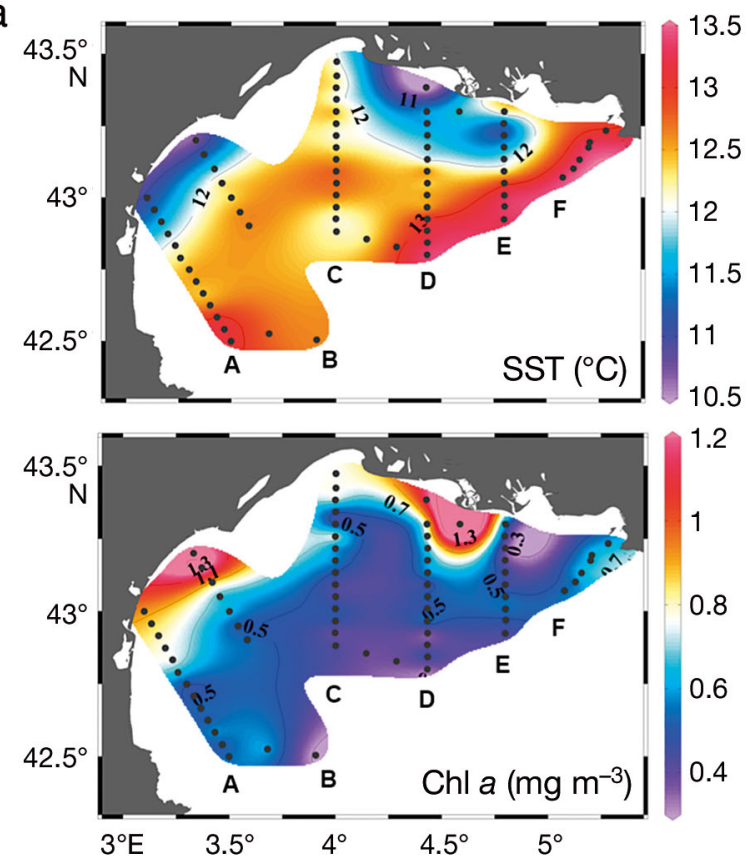

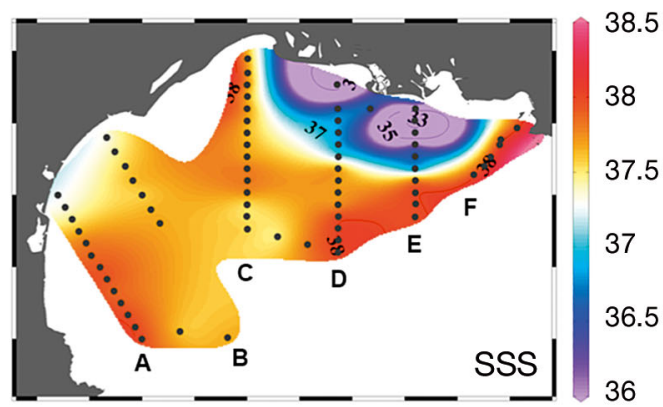

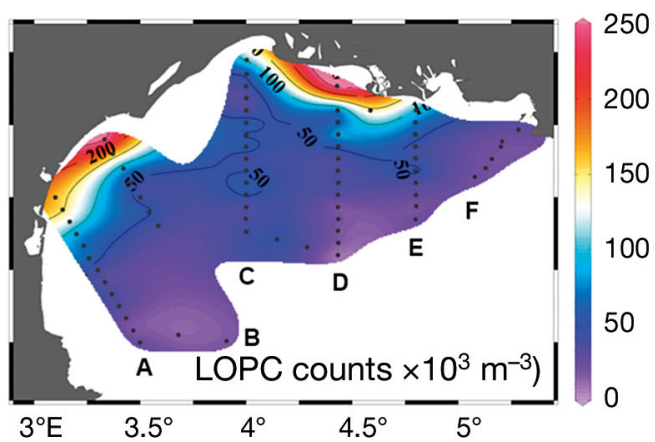

b
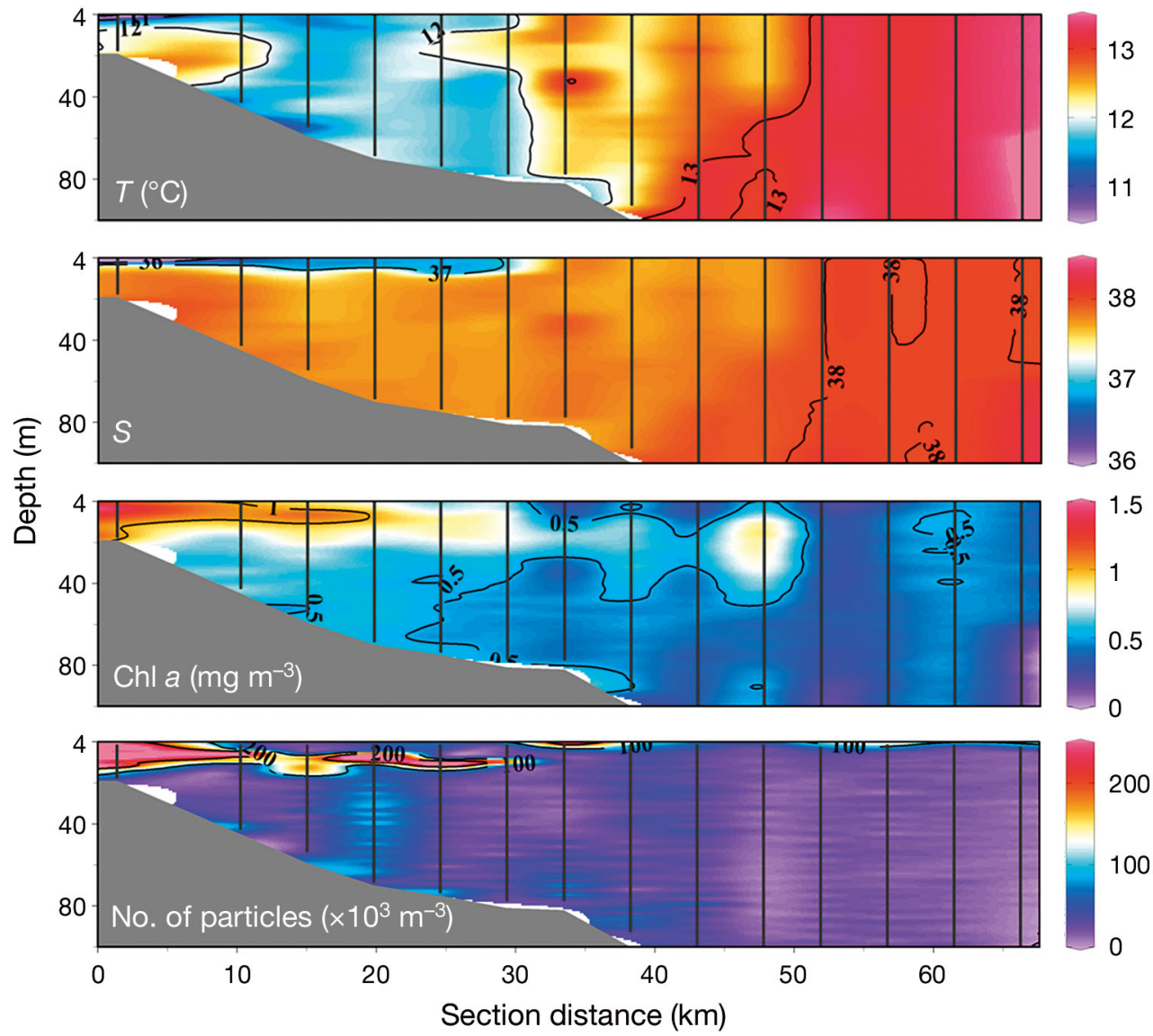

Fig. 3. COSTEAU 6 (23 to 27 January 2011): (a) Spatial distributions of sea surface temperature (SST), sea surface salinity (SSS), chlorophyll a (chl a) concentration, and particle concentration (laser optical particle counter [LOPC] counts, 0.1-35 mm equivalent spherical diameter [ESD]). Stations are represented by the black dots and Transects A-F are indicated. (b) Vertical distributions of sea temperature $(T)$, sea salinity $(S)$, chl a concentration, and particle concentration along Transect D. Black vertical lines represent the fluorometer-CTD-LOPC casts 
In May 2010, the Rhône outflow affected a large part of the Gulf of Lion, far out to the west to the coast and to the south up to the continental slope $(S<37$ and $T>16^{\circ} \mathrm{C}_{i}$ Fig. $4 \mathrm{a}$ ). The tip of the plume curved slightly westward. At the surface, continental shelf waters were only visible in the eastern part of the gulf $(S>38)$. Transect D in front of the mouth of the Little Rhône crossed the tip of the Great Rhône plume. The spring warming of the surface waters stratifies the water column along the whole transect. In the vicinity of the Rhône River plume, mixing of warmer waters with the fresh water of the plume created a strong potential density gradient between the surface and bottom layers. The pycnocline was at a depth of around $12 \mathrm{~m}$ (Fig. 4b).

\section{Chlorophyll $a$ and zooplankton distributions}

During the winter survey (23 to 27 January 2011), the integrated chl a concentrations were highest in coastal waters, in front of the Rhône estuaries and in the coldest waters in the western part of the gulf (Fig. 3a). However, concentrations on the continental shelf were fairly high, generally over $0.5 \mathrm{mg} \mathrm{m}^{-3}$. In the center of the gulf, the vertical distributions showed 3 identifiable patterns (Fig. 3b): the highest concentrations were situated near the coast in the subsurface water layer affected by freshwater inputs, intermediate concentrations were found in continental shelf waters, and the lowest concentrations were in the oligotrophic waters of the NC.

The distributions of particle concentrations were correlated with chl a distributions: the highest concentrations were found near the coast in the western part of the gulf and in front of the estuaries, especially that of the Little Rhône (Fig. 3a). On the continental shelf, the particle concentrations were lower but uniform. In the water column, high particle concentrations were concentrated in a thin layer centered on the pycnocline (Fig. 3b). Farther offshore, some smaller patches appeared near the surface.

During the spring survey (27 April to 2 May 2010), vertically integrated chl a concentrations were not uniformly distributed and, although there were a few hot spots in the coastal area, concentrations were lower than in January (Fig. 4a). Mean concentrations on the continental shelf were also quite low compared to January $\left(<0.3 \mathrm{mg} \mathrm{m}^{-3}\right)$. Along transect $\mathrm{D}$, chl a vertical distributions were very patchy (Fig. $4 \mathrm{~b}$ ). The highest concentrations were found in the freshest waters at the tip of the Rhône River plume
(>1.5 $\mathrm{mg} \mathrm{m}^{-3}$ ). Deeper, about $40 \mathrm{~m}$, concentrations occasionally reached $0.5 \mathrm{mg} \mathrm{m}^{-3}$.

The highest particle concentrations were in the coastal area, in both the western and eastern parts of the gulf $\left(>150 \times 10^{3}\right.$ counts $\mathrm{m}^{-3}$; Fig. $\left.4 \mathrm{a}\right)$. High particle concentrations, correlated with the spatial distribution of the Rhône River plume, were also present far from the coast on the shelf. Vertical particle distributions show several patches distributed in the subsurface layer at the interface between the warm surface waters and the colder continental shelf waters (Fig. 4b). The highest concentrations were found in the Rhône River plume $\left(>400 \times 10^{3}\right.$ counts $\left.\mathrm{m}^{-3}\right)$. Concentrations under the pycnocline were quite low $\left(>30 \times 10^{3}\right.$ counts $\left.\mathrm{m}^{-3}\right)$, although several hot spots appeared near the bottom on the shelf up to the continental slope.

\section{Analytical results}

Statistical tests were performed separately for each data set. In January, the first PC calculated by the PCA had positive coordinates for mixed layer depth and sea surface temperature and negative coordinates for small- and medium-sized particles (Table 3). The second component was defined by the stratification index and the NBSS slope on the positive side and sea surface salinity on the negative. The correlation circle formed by PCs 1 and 2 (Fig. 5a) shows a positive correlation between the abundance of small particles and chl a concentration, and between the stratification index and the abundance of large particles.

In May, the main pattern from the variable coordinates was a positive correlation between water column stratification (Rho_grad, Temp_0, and Sal_0) and the abundance of large particles (Table 3). The second component showed that the NBSS slopes were negatively correlated with chl a concentrations and the abundance of small particles. Some of the patterns highlighted by the correlation circle (Fig. 5b) were similar to those found for the January data (Fig. 5a), with similar correlations between the water column stratification and the abundance of large particles and between chl a concentrations and the abundance of small particles.

Stations D1 and E1 were considered as outliers for COSTEAU 6 (January) and COSTEAU 4 (May), respectively. These stations gave extreme values which were clearly different from the other stations (Fig. 6). Station D1 was the shallowest station (15 m depth) with extreme values for chl $a$ and particle concentrations. Station E1, in front of the Rhône River 
a
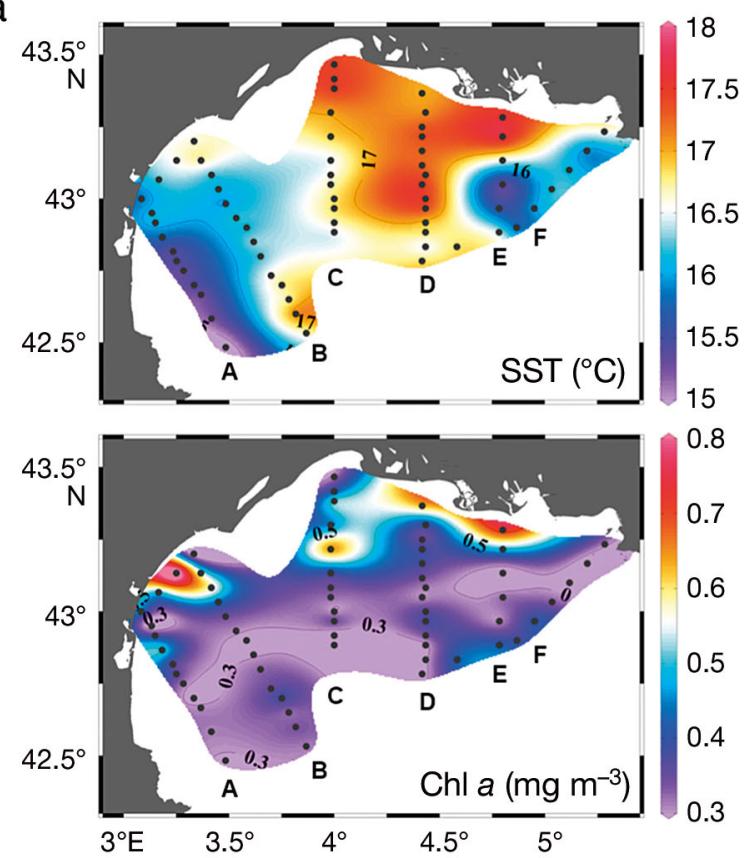
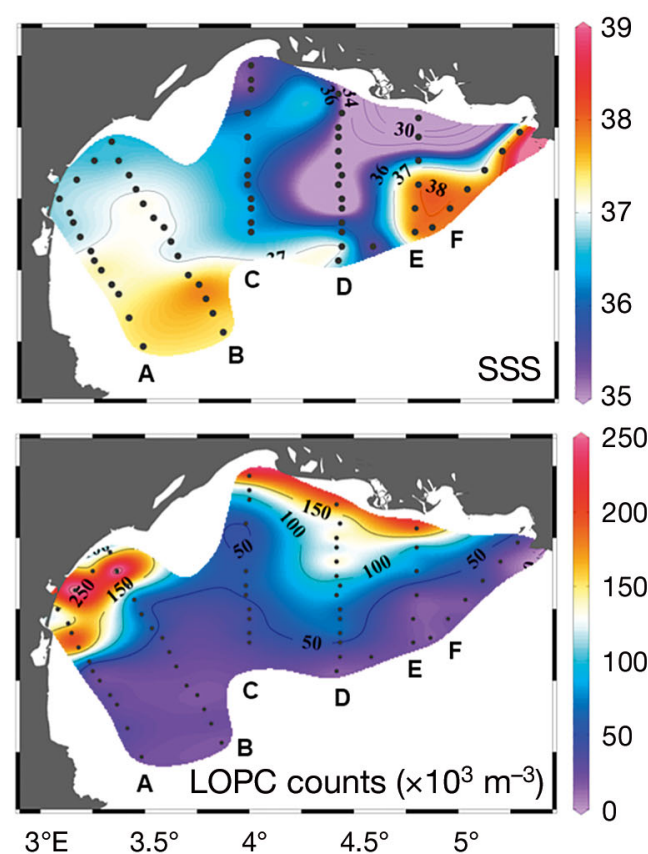

b
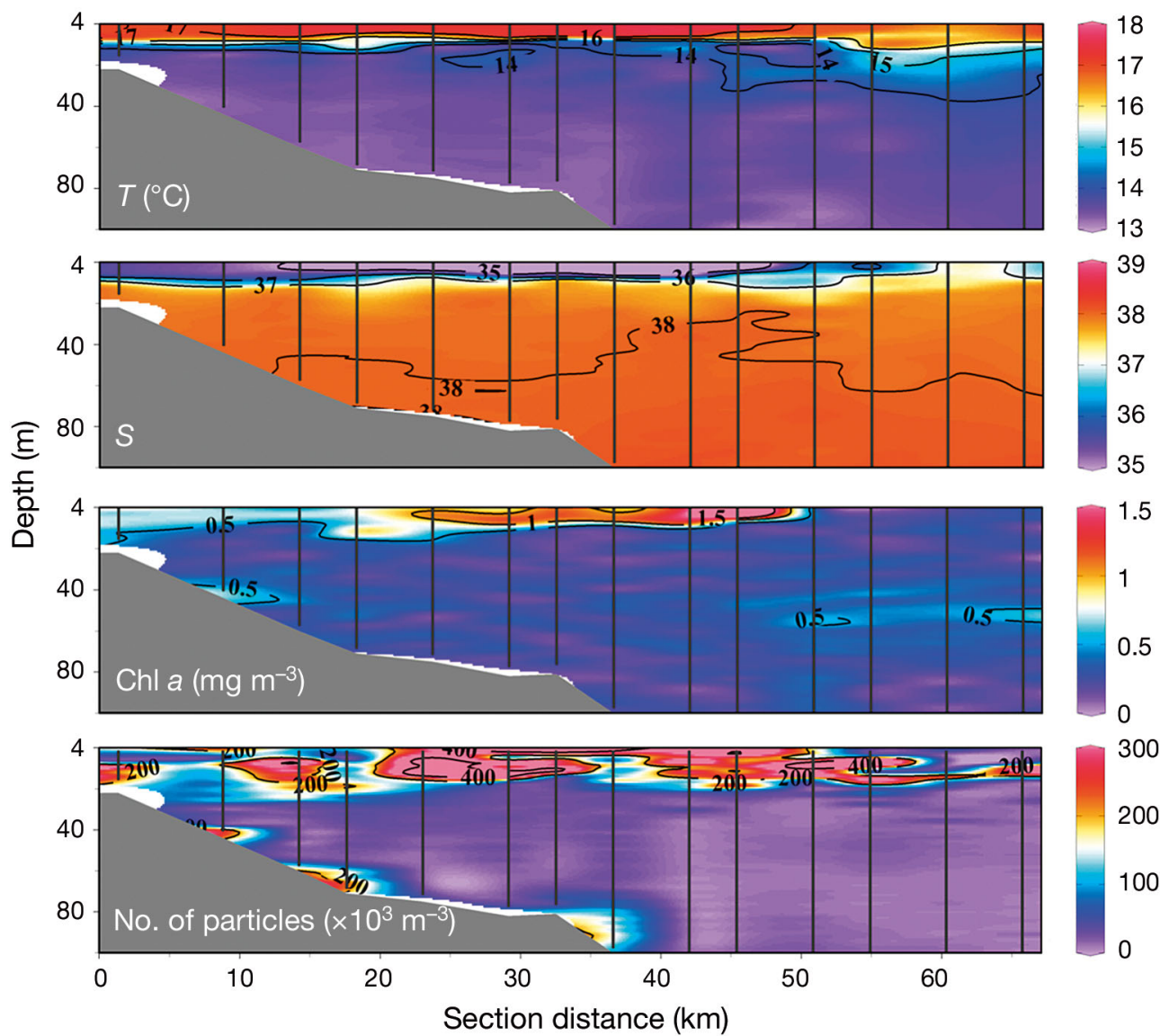

Fig. 4. COSTEAU 4 (27 April to 2 May 2010): (a) Spatial distributions of sea surface temperature (SST), sea surface salinity (SSS), chlorophyll a ( $\mathrm{chl}$ a) concentration, and particle concentration (laser optical particle counter [LOPC] counts, 0.1-35 mm equivalent spherical diameter [ESD]). Stations are represented by the black dots and Transects A-F are indicated. (b) Vertical distributions of sea temperature $(T)$, sea salinity $(S)$, chl a concentration, and particle concentration along Transect D. Black vertical lines represent the F-CTD-LOPC casts 
Table 3. Correlation coefficients of the parameters (with percentages of the total variance in parentheses) for the 3 first principal components for COSTEAU 6 (January) and COSTEAU 4 (May). Significant coefficients of each component are shown in bold. Parameter abbreviations are defined in Table 2; NBSS: normalized biomass size spectrum

\begin{tabular}{|c|c|c|c|c|c|c|}
\hline \multirow{3}{*}{$\begin{array}{l}\text { Para- } \\
\text { meter }\end{array}$} & \multicolumn{3}{|c|}{- COSTEAU $6-$} & \multicolumn{3}{|c|}{$\longrightarrow$ COSTEAU 4} \\
\hline & PC1 & PC2 & PC3 & PC1 & PC2 & PC3 \\
\hline & \multicolumn{3}{|c|}{$(-44.50 \%)(-24.70 \%)(-13.50 \%)$} & \multicolumn{3}{|c|}{$(-43.90 \%)(-19.90 \%)(-11.60 \%)$} \\
\hline Z_ML & 0.79 & -0.16 & -0.39 & 0.5 & 0.24 & 0.54 \\
\hline Rho_grad & -0.51 & 0.76 & 0.06 & -0.75 & 0.45 & -0.29 \\
\hline Temp_0 & 0.89 & 0.03 & -0.16 & -0.78 & 0.3 & -0.22 \\
\hline Sal_0 & 0.66 & -0.65 & -0.16 & 0.82 & -0.37 & 0.28 \\
\hline Rho_b & 0.13 & 0.38 & 0.72 & 0.44 & 0 & -0.57 \\
\hline Chla_int & -0.67 & -0.55 & -0.12 & -0.39 & -0.56 & -0.02 \\
\hline$X_{0.1-0.3 \mathrm{~mm}}$ & -0.84 & -0.47 & -0.09 & -0.7 & -0.62 & 0.06 \\
\hline$X_{0.3-0.5 \mathrm{~mm}}$ & -0.89 & -0.03 & -0.32 & -0.86 & -0.26 & 0.29 \\
\hline$X_{0.5 \mathrm{~mm}}$ & -0.4 & 0.59 & -0.59 & -0.8 & 0.12 & 0.43 \\
\hline NBSS slope & 0.46 & 0.65 & -0.39 & -0.03 & 0.85 & 0.25 \\
\hline
\end{tabular}

mouth, was characterized by the freshest surface waters $($ Sal_0 $<25)$ and therefore a very stratified water column (Rho_grad very high).

\section{Habitat mapping}

The plot of the 3 groups of stations defined by the cluster analysis produced a consistent spatial representation for the 2 surveys (Fig. 7). In January, Habitat 2 contained only 3 stations directly in front of the Rhône River mouth, whereas in May this habitat covered a large area in front of the Rhône River mouth and along the coast to the west. Habitat 1 cov-
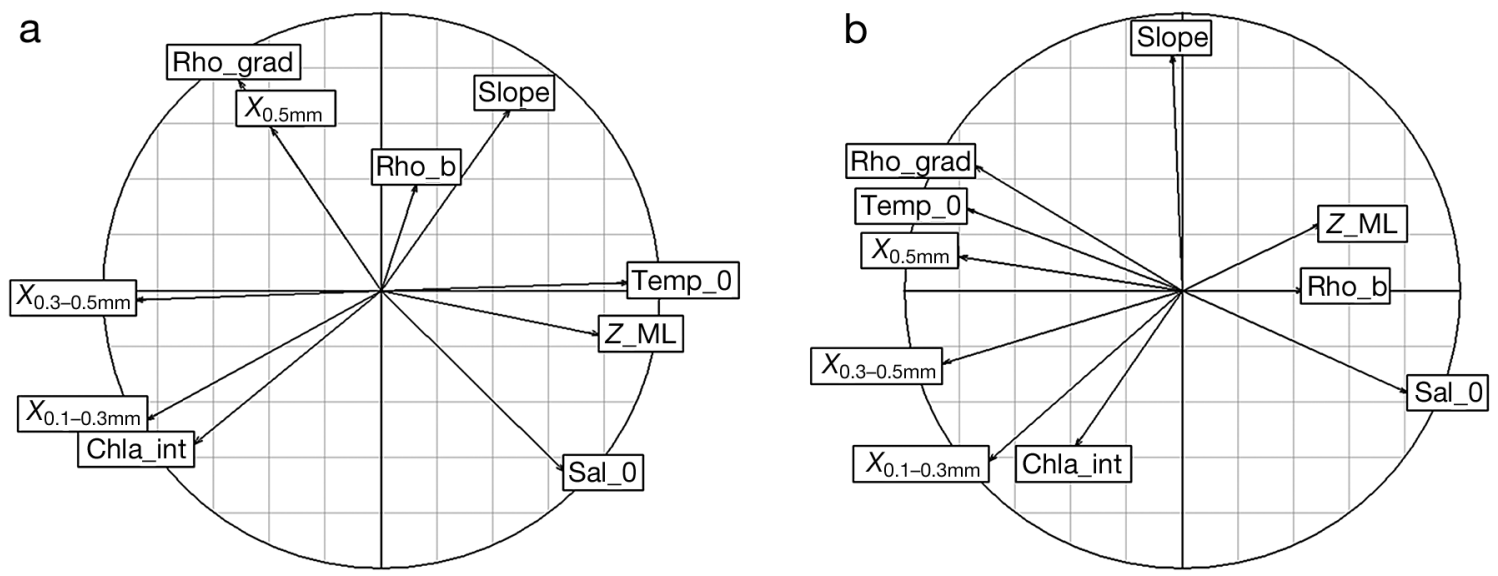

Fig. 5. Principal component analysis correlation circle on axes 1 and 2 for (a) COSTEAU 6 (January) and (b) COSTEAU 4 (May). Abbreviations are given in Table 2
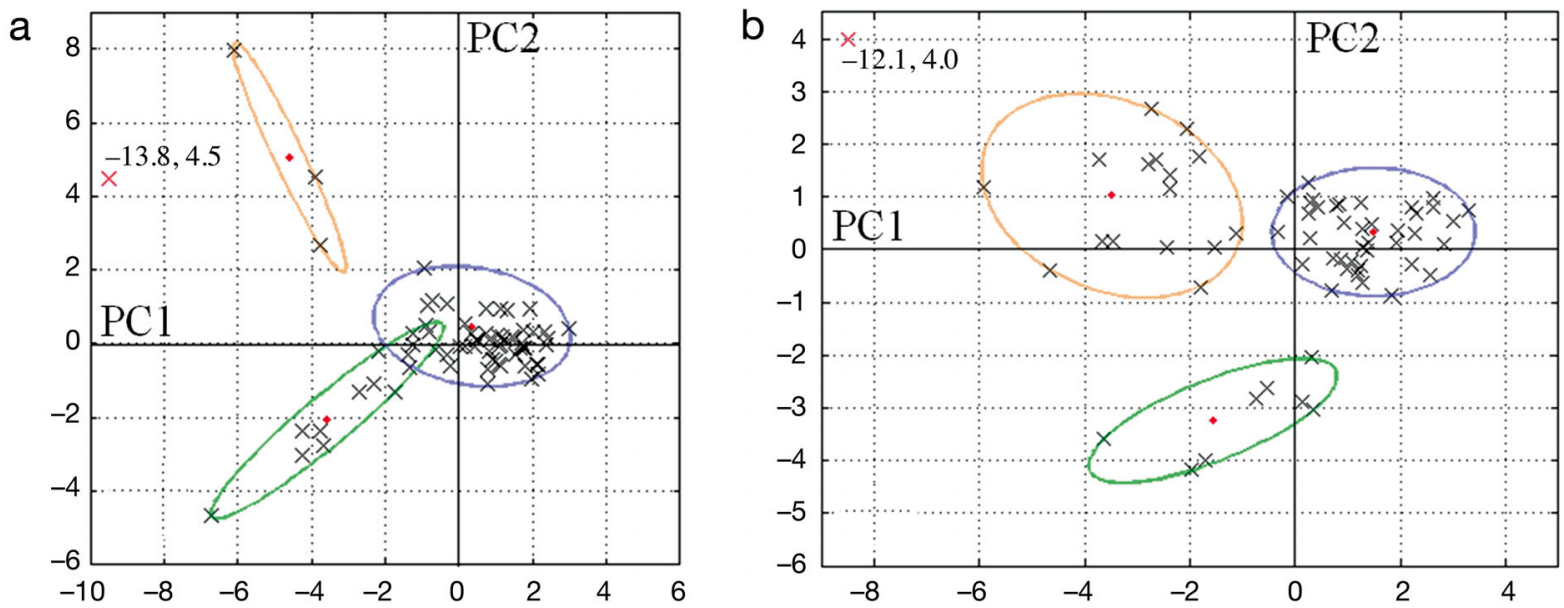

Fig. 6. Positions of the stations (gray crosses) in the plane formed by the first 2 principal components for (a) COSTEAU 6 (January) and (b) COSTEAU 4 (May). The results of cluster analysis are represented using the minimum volume enclosing ellipsoid function. Red crosses represent (a) Station D1 and (b) Station E1, which are considered to be outliers. Red diamonds represent the centers of the ellipses 

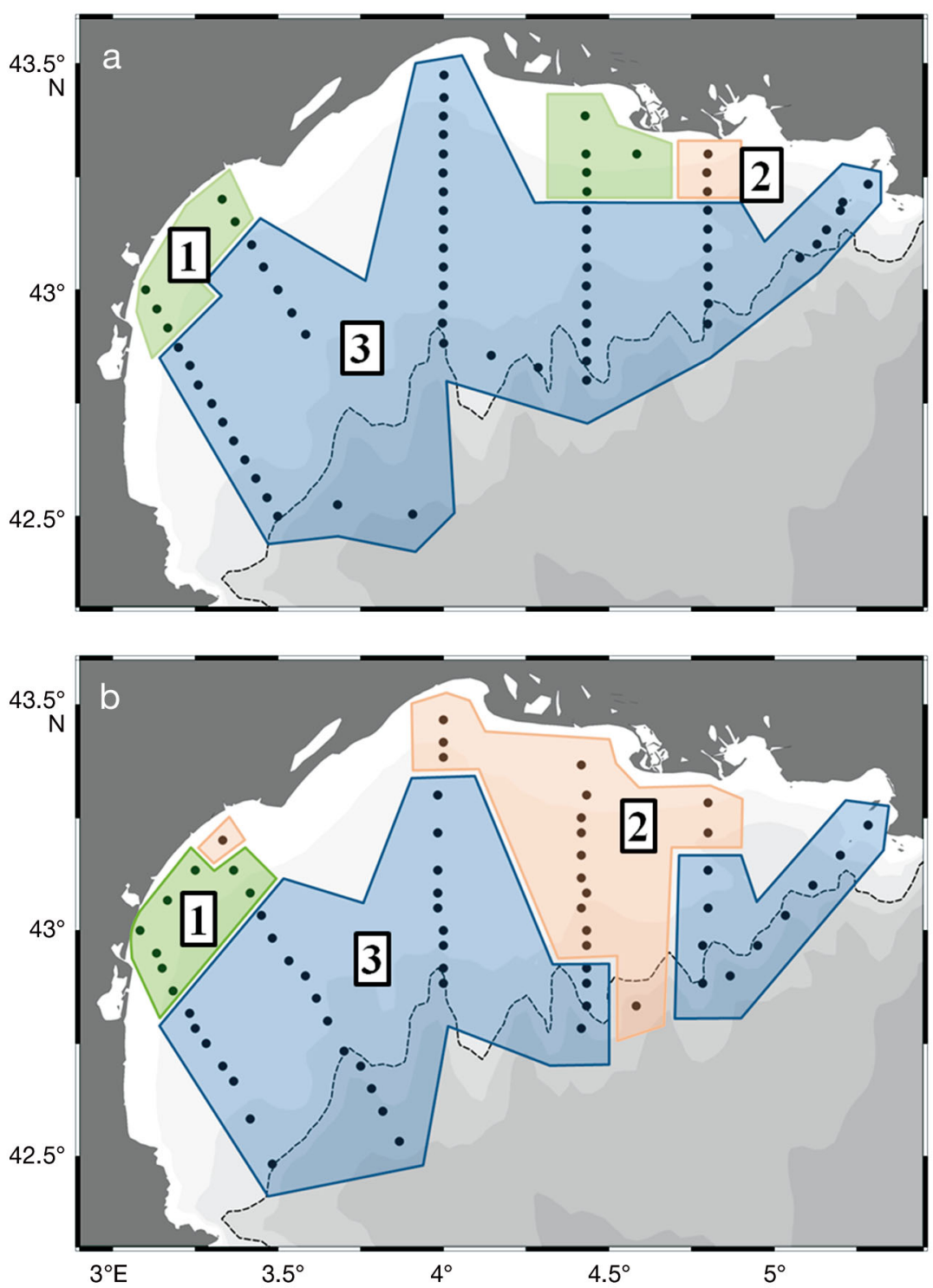

Fig. 7. Spatial distribution of the 3 habitats defined by the cluster analysis for (a) COSTEAU 6 (January) and (b) COSTEAU 4 (May). Habitat 1 (green) corresponds to 'coastal area,' Habitat 2 (red) to 'area affected by the Rhône,' and

Habitat 3 (blue) to 'continental shelf.' Black dots represent the stations ered only the west part of the coast in May, but in January it included an additional area in the center. Habitat 3 was the most extensive of the 3 habitats, containing all stations situated along the slope and in the eastern part of the gulf to the Bay of Marseilles. There were similarities between the distribution and the characteristics of the 3 habitats even though statistical tests were performed independently on the 2 data sets. The means of the variables defining the 3 habitats showed the following features (Table 4):

- Habitat 1, coastal area: shallow waters, steep NBSS slope, high chl a concentration

- Habitat 2, area affected by the Rhône: marked stratification, flat NBSS slope

- Habitat 3, continental shelf: deep mixed layer, low density gradient, low particle concentrations

\section{Habitat characteristics}

To confirm the definition of the habitats, the size spectra of living and nonliving particles from $100 \mu \mathrm{m}$ to $5 \mathrm{~mm}$ ESD were investigated using NBSS (Fig. 8). NBSS showed different patterns between the 2 surveys in each of the 3 habitats. In general, NBSS shapes were linear in January whereas a break point appeared around $1.5 \log (\mu \mathrm{g})$ for May stations, and the mean NBSS slopes were steeper in January than in May. Within each survey, the NBSS slopes were steepest in Habitat 1, ow-

Table 4. Mean values of the parameters within the 3 habitats for the 2 campaigns. Parameter abbreviations are defined in Table 2; NBSS: normalized biomass size spectrum

\begin{tabular}{|lrrrrrrrrrr|}
\hline & Z_ML & Rho_grad & Temp_0 & Sal_0 & Rho_b & Chla_int & $X_{0.1-0.3 \mathrm{~mm}}$ & $X_{0.3-0.5 \mathrm{~mm}}$ & $X_{0.5 \mathrm{~mm}}$ & NBSS slope \\
\hline January & & & & & & & & & \\
Habitat 1 & 18 & 0.07 & 11.35 & 37.08 & 28.69 & 0.93 & 127910 & 6119 & 890 & -1.15 \\
Habitat 2 & 1 & 1.46 & 11.57 & 33.88 & 28.71 & 0.47 & 63480 & 7610 & 2730 & -0.79 \\
Habitat 3 & 74 & 0.02 & 12.58 & 37.70 & 28.70 & 0.53 & 35620 & 2932 & 1207 & -0.85 \\
May & & & & & & & & & \\
Habitat 1 & 1.8 & 0.13 & 16.16 & 36.78 & 28.72 & 0.50 & 165491 & 14800 & 3075 & -1.03 \\
Habitat 2 & 2.6 & 0.59 & 17.26 & 34.95 & 28.64 & 0.38 & 89478 & 15480 & 6389 & -0.74 \\
Habitat 3 & 5.3 & 0.13 & 16.19 & 37.07 & 28.73 & 0.32 & 31656 & 4698 & 1632 & -0.80 \\
\hline
\end{tabular}



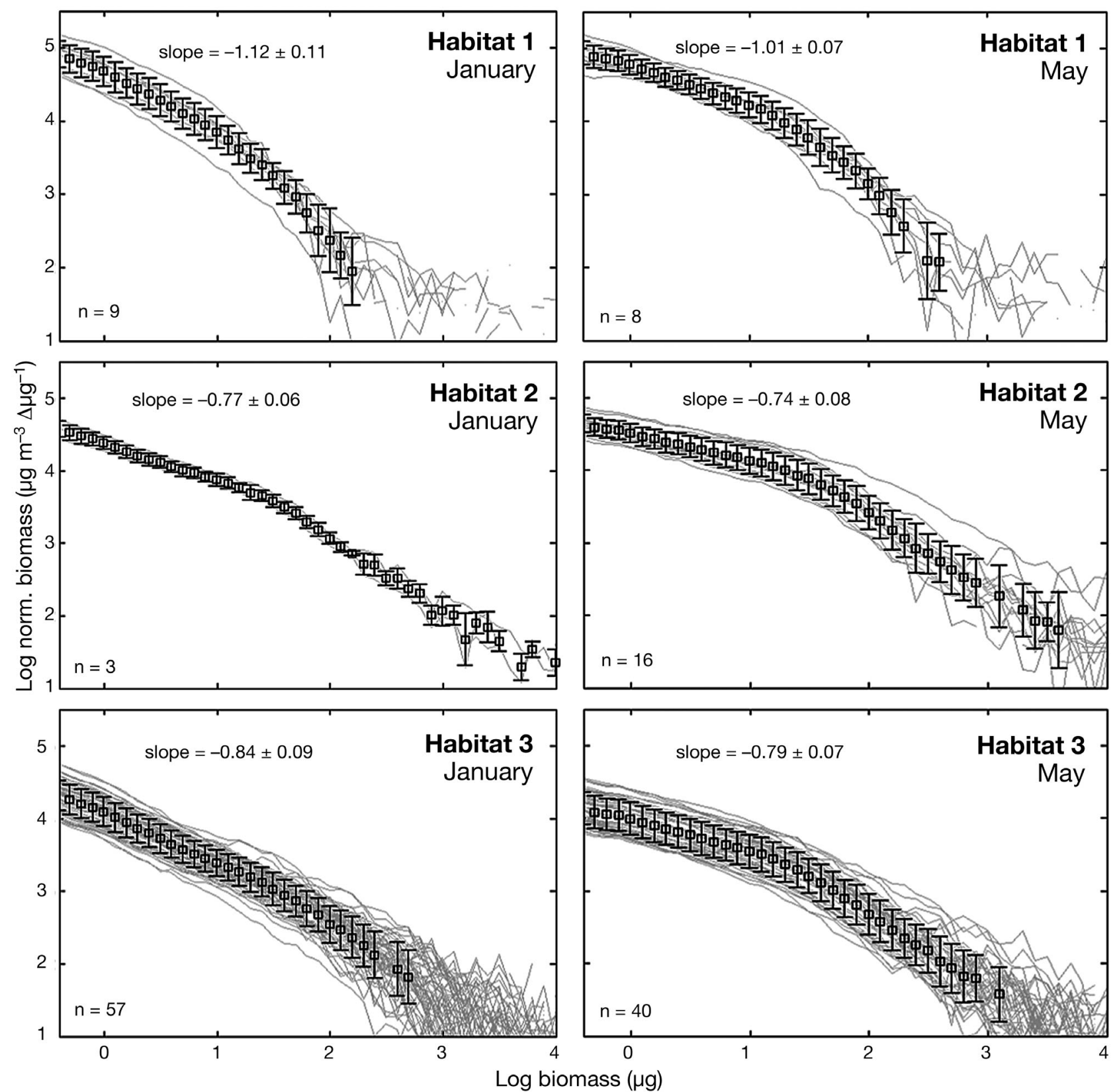

Fig. 8. Normalized biomass size spectrum (NBSS) of the stations (light grey lines) included in the 3 habitats (see Fig. 7) for the 2 campaigns. The mean NBSS and standard deviation for each habitat is represented by the squares and the error bars. Mean NBSS slopes ( \pm SD) and number of stations (n) are shown

ing to the high abundances of small particles $(<0.9$ $\log (\mu \mathrm{g})_{;} 0.3 \mathrm{~mm}$ ESD) and flattest in Habitat 2, owing to the high abundances of large particles $(>1.6$ $\log (\mu \mathrm{g}) ; 0.5 \mathrm{~mm}$ ESD). In Habitat 3, NBSS slopes had intermediate values and a lower $y$-intercept.

Based on the spatial proportion, i.e. the ratio between the number of stations included in the habitat and the total number of stations, and the mean particle concentrations in each habitat (Table 4), the indi- cators of the contributions to the global zooplankton stock were calculated for 3 size classes in January and May (Table 5). In January, most of the medium to large organisms were concentrated in the continental shelf habitat, while the small organisms used both the continental shelf and the coastal area. In May, most of the large organisms were in the area affected by the Rhône, while small organisms were equally distributed across the 3 habitats. 
Table 5. Indicators of zooplankton stock for each habitat estimated from the spatial proportion and the mean particle concentrations (VS: very small; S: small; M: medium; L: large, VL: very large) within 3 size classes during January and May surveys. Spatial distribution of the habitats is shown in Fig. 7 and mean particle concentrations in Table 4

\begin{tabular}{|ccccccccc|}
\hline & \multicolumn{3}{c}{ January } & & \multicolumn{3}{c|}{ May } \\
\cline { 2 - 4 } \cline { 7 - 8 } & $X_{0.1-0.3 \mathrm{~mm}}$ & $X_{0.3-0.5 \mathrm{~mm}}$ & $X_{0.5 \mathrm{~mm}}$ & & $X_{0.1-0.3 \mathrm{~mm}}$ & $X_{0.3-0.5 \mathrm{~mm}}$ & $X_{0.5 \mathrm{~mm}}$ \\
\hline Habitat 1 & $\mathrm{L}$ & $\mathrm{M}$ & $\mathrm{S}$ & & $\mathrm{M}$ & $\mathrm{S}$ & $\mathrm{S}$ \\
Habitat 2 & $\mathrm{VS}$ & $\mathrm{S}$ & $\mathrm{S}$ & & $\mathrm{M}$ & $\mathrm{L}$ & $\mathrm{VL}$ \\
Habitat 3 & $\mathrm{L}$ & $\mathrm{VL}$ & $\mathrm{VL}$ & & $\mathrm{M}$ & $\mathrm{M}$ & $\mathrm{L}$ \\
\hline
\end{tabular}

\section{DISCUSSION}

\section{LOPC data}

The use of in situ optical counters in coastal regions and stratified waters could be tricky owing to high particle concentration peaks caused by resuspension and aggregation processes. For the LOPC, coincidence issues could result in incoherent multielement plankton (MEP) sequences and an overestimation of large-particle abundances. Schultes \& Lopes (2009) suggested the ratio of Total Count (TC):MEP Count as an indicator to show whether a profile is coherent. If this ratio drops below 20, the system has been probably overloaded by MEP counts during counting. In the present study, incoherent MEP sequences appeared in stratified waters (9 out of 135 stations) and did not always correspond to a TC:MEP ratio below 20 (2 out of 135 stations). This is probably because the ratio was integrated along the water column and its mean value will depend on the height of the water column under the pycnocline, where the ratio is generally very low owing to high transparent aggregate concentrations. Basedow et al. (2014) showed that in polar regions, a low TC:MEP ratio can also be the result of a high concentration of large organisms. In all cases, the number of profiles concerned in this study is low and we consider that the conditions were suitable for LOPC during the surveys.

\section{Physical processes}

The regions of freshwater influence (Simpson 1997) for the Rhône River were different for the 2 surveys. The plume position, movement, and dilution were closely associated with wind conditions. During the January survey, strong northerly winds mixed the water column and diluted the Rhône River plume, leaving only a small area affected by the freshwater input. In May, a lens of freshwater was separated from the rest of the plume (Fig. 4a). Light winds pushed the plume southwards. At the same time, the Coriolis force caused the tip of the plume to drift to the west (Ekman transport). The creation of freshwater lenses and, more generally, the stratification of the water column at this time imply that a large part of the gulf was affected by the Rhône River discharge during the May survey.

The NC separates the continental shelf from the open sea. Intrusions were recorded along Transect D in the east of the gulf in January (Fig. 3b). At this time, the NC was narrow, strong, and close to the slope with frequent intrusions onto the shelf (Estournel et al. 2003, Petrenko 2003). Saltier and ultra-oligotrophic waters carried by the NC intrude onto the shelf and create a front with the continental shelf waters. In the coastal western part of the gulf, the cold, strong northerly winds cool the shallowest waters and mix them with freshwaters coming from the Rhône River and other sources (Broche et al. 1998, Petrenko 2003).

\section{Environmental conditions}

Hydrodynamic conditions in the coastal area have a significant influence on the distribution and availability of nutrients and therefore drive the distribution and the population dynamics of primary producers. In the Gulf of Lion, the winds and the fluvial inputs are the 2 main factors affecting the physical structures. The combination of these 2 factors creates 2 main highly productive areas, viz. the nearshore area and the area where the Rhône river plume is diluted (Champalbert 1996, Lefevre et al. 1997, Gaudy et al. 2003), corresponding to 2 of the 3 habitats identified by statistical analysis in this study.

The habitat in the nearshore area is characterized by shallow mixed waters and high chl a concentrations. In this area (<50 m depth), biological production was increased by nutrient-rich freshwater discharges and wind-driven resuspension, especially in the western part, where there are many river mouths and the Tramontane is frequent and strong.

The habitat in the area affected by the Rhône waters is characterized by stratified waters caused by the freshwater runoff in a thin surface layer. The Rhône River plume has food webs that are time dependent and can be divided into several steps from microbial loop dominance at the mouth, to large size 
phytoplankton production a few days later (Diaz et al. 2008). The combination of high chl a concentration in the surface waters with a stratified water column results in an increase in biomass at the interface of the water masses which is caused by a slowing down of the sinking biomass and aggregation processes at the pycnocline (Alldredge et al. 2002, Checkley et al. 2008, Jackson \& Checkley 2011). This represents an important source of food for zooplankton which come to feed at the front between the water masses (Gaudy et al. 1990, 1996, Pagano et al. 1993). The spread of this habitat is closely linked to the hydroclimatic conditions, especially thermal stratification and wind.

The third habitat was characterized by the mean conditions on the continental shelf and was less affected by coastal dynamic variability. The biological production was lower in this area than in the other 2 habitats, owing to the oligotrophic influence of the NC and to the lack of nutrient inputs.

\section{Zooplankton habitats}

Based on the zooplankton size structure and the environmental conditions, 3 zooplankton habitats were defined (Table 4, Fig. 7). In this study, vertical information was integrated to produce 2D habitat maps that are easier to use and visualize. Defining habitats is a statistical way of analyzing the distribution of zooplankton communities as a function of environmental conditions (Zarauz et al. 2007, Schulz et al. 2012). This approach is particularly useful for continental shelves and, more generally, coastal areas where changing physical structures have a significant effect on the marine ecosystems by creating different environmental patterns. Given the variability of the physical structures, habitats can only be identified by mapping the study area at high spatial resolution and checking that the physical structures are stable during the surveys. Using in situ optical captors was less time-consuming than traditional sampling and provides characteristics of size spectra as indicators of zooplankton communities. The processes which shape the habitats lead to different zooplankton size structure characterized by changes in NBSS slopes (Fig. 8).

Mixed-water ecosystems are known to promote small mesozooplankton production (Jackson et al. 1997, Checkley et al. 2008), which is in agreement with the steep NBSS measured in the nearshore habitat. It is likely that the highly variable hydrological conditions in the shallowest waters are not favorable to the development of large-sized species. The steepness of the slope indicates a short food web adapted to episodic phytoplankton bloom driven by winds. This habitat is the most productive during the winter and supports biological production within the Gulf of Lion when production on the shelf is low (Kouwenberg 1994, Gaudy et al. 2003). Moreover, despite the small area covered by this habitat, there was a large stock of small-sized species in January (Table 5).

Stratified ecosystems encourage the development of large copepods (Williams et al. 1994, Poulet et al. 1996, Sourisseau \& Carlotti 2006), which is confirmed by the flat NBSS found in the habitat closely associated with the spreading of the Rhône waters. The diversity of food sources prevented food limitation for zooplankton and encouraged the biodiversity of species resulting in the ecosystem being efficient at transferring the biomass from the small to large organisms, illustrated by the flattening of the slopes (Zhou et al. 2009, Basedow et al. 2010). When the water is stratified and the Rhône waters are spread widely, as during the May survey, this habitat is a refuge for large zooplankton species (Table 5).

A coastal to offshore gradient in particle concentrations was observed during this study which agrees with previous surveys conducted in the Gulf of Lion (Kouwenberg 1994, Gaudy et al. 2003). The third habitat was the main part of the continental shelf, the continental slope, and the eastern end of the gulf and had lower particle concentrations than the other habitats. The oligotrophic influence of the NC was clear, especially in the eastern part of the shelf. However, this habitat is larger than the other 2 and is an important reserve for large species during the winter (Table 5).

The differences between the NBSSs for the habitats confirm that the size structures and, therefore, zooplankton communities were not the same, showing that they were distinct zooplankton habitats, or 'guilds,' according to the classification proposed by Costello (2009).

\section{Use and future of habitat definition}

Based on data from field samples over 2 periods, our study shows a significant correlation between physical and biological features (Fig. 5, Table 3). Although statistical analysis was performed separately on the data sets for each survey, the characteristics of the habitats are similar. This is due to the permanent presence of certain processes, such as the 
Rhône water runoff and the wind-driven mixing of coastal waters, which drive the distribution of the habitats. Therefore, changes in the distribution of habitats can be determined by identifying the variables which characterize these processes and by estimating the values of these variables at high spatio-temporal resolution using simulations from hydrological models (Planque et al. 2004, Zarauz et al. 2007). Remote sensing data also provide certain variables that are characteristic of the surface layer. These types of data can be used to determine spatial distribution of the habitats during the year.

Defining habitats provides a firm basis for developing efficient sampling strategies for studying zooplankton dynamics by defining a limited number of stations that are representative of specific conditions. By mapping large, consistent habitats to collate the information on zooplankton distribution and characteristics, defining habitats is the best way of including zooplankton communities in trophodynamic studies, especially in the Gulf of Lion which is considered to be one of the main reproduction areas for small pelagic species (Plounevez \& Champalbert 2000, Palomera et al. 2007). Furthermore, determining habitats with distinct zooplankton size structures provides important information given that recent studies have highlighted the role of prey size in the recruitment success of fish larvae (Irigoien et al. 2009, Costalago et al. 2011). Defining habitats would also be useful for validating zooplankton distribution models and estimating indicators of zooplankton stocks in different parts of and over the whole gulf, as shown in Table 5. This type of information is suitable for coastal management programs, such as coastal ecosystem observatory networks, in order to determine the best means for protecting and preserving coastal marine ecosystems.

Acknowledgements. We acknowledge the Captain and crews of the RV 'Téthys II' for their assistance during the cruise. We thank A. Desnues for the laboratory assessment of chl a concentrations. This study was supported by the Agence Nationale de la Recherche (ANR): ANR COSTAS funded the research cruises and laboratory analysis, whereas the ANR FOCEA funded the optical sensors implemented and used during the cruises and the data analysis from these captors. The manuscript was improved by comments from 3 anonymous reviewers.

\section{LITERATURE CITED}

Alldredge AL, Cowles TJ, MacIntyre S, Rines JEB and others (2002) Occurrence and mechanisms of formation of a dramatic thin layer of marine snow in a shallow Pacific fjord. Mar Ecol Prog Ser 233:1-12
Aminot A, Kérouel R (2004) Hydrologie des écosystèmes marins: paramètres et analyses. Ifremer, Plouzané

Andersen KH, Beyer JE, Lundberg P (2009) Trophic and individual efficiencies of size-structured communities. Proc R Soc Lond B Biol Sci 276:109-114

André G, Garreau P, Garnier V, Fraunié P (2005) Modelled variability of the sea surface circulation in the Northwestern Mediterranean Sea and in the Gulf of Lions. Ocean Dyn 55:294-308

Bănaru D, Mellon-Duval C, Roos D, Bigot JL and others (2013) Trophic structure in the Gulf of Lions marine ecosystem (north-western Mediterranean Sea) and fishing impacts. J Mar Syst 111-112:45-68

Basedow SL, Tande KS, Zhou M (2010) Biovolume spectrum theories applied: spatial patterns of trophic levels within a mesozooplankton community at the polar front. J Plankton Res 32:1105-1119

Basedow SL, Tande KS, Norrbin MF, Kristiansen SA (2013) Capturing quantitative zooplankton information in the sea: performance test of laser optical plankton counter and video plankton recorder in a Calanus finmarchicus dominated summer situation. Prog Oceanogr 108:72-80

> Basedow SL, Zhou M, Tande KS (2014) Secondary production at the Polar Front, Barents Sea, August 2007. J Mar Syst 130:147-159

Bellido J, Brown A, Valavanis V, Giráldez A, Pierce G, Iglesias M, Palialexis A (2008) Identifying essential fish habitat for small pelagic species in Spanish Mediterranean waters. Hydrobiologia 612:171-184

- Broche P, Devenon JL, Forget P, de Maistre JC, Naudin JJ, Cauwet G (1998) Experimental study of the Rhone plume. Part I: physics and dynamics. Oceanol Acta 21:725-738

Champalbert G (1996) Characteristics of zooplankton standing stock and communities in the Western Mediterranean Sea: relations to hydrology. Sci Mar 60:97-113

Checkley DM Jr, Davis RE, Herman AW, Jackson GA, Beanlands B, Regier LA (2008) Assessing plankton and other particles in situ with the SOLOPC. Limnol Oceanogr 53: 2123-2136

Costalago D, Tecchio S, Palomera I, Álvarez-Calleja I, Ospina-Álvarez A, Raicevich S (2011) Ecological understanding for fishery management: condition and growth of anchovy late larvae during different seasons in the Northwestern Mediterranean. Estuar Coast Shelf Sci 93:350-358

> Costalago D, Navarro J, Álvarez-Calleja I, Palomera I (2012) Ontogenetic and seasonal changes in the feeding habits and trophic levels of two small pelagic fish species. Mar Ecol Prog Ser 460:169-181

> Costello MJ (2009) Distinguishing marine habitat classification concepts for ecological data management. Mar Ecol Prog Ser 397:253-268

> Davies DL, Bouldin DW (1979) A cluster separation measure. IEEE Trans Pattern Anal Machine Intellig 1:224-227

- Davis CS, Hu Q, Gallager SM, Tang X, Ashjian CJ (2004) Real-time observation of taxa-specific plankton distributions: an optical sampling method. Mar Ecol Prog Ser 284:77-96

- Diaz F, Naudin JJ, Courties C, Rimmelin P, Oriol L (2008) Biogeochemical and ecological functioning of the lowsalinity water lenses in the region of the Rhone River freshwater influence, NW Mediterranean Sea. Cont Shelf Res 28:1511-1526

Estournel C, Durrieu de Madron X, Marsaleix P, Auclair F, Julliand C, Vehil R (2003) Observation and modeling 
of the winter coastal oceanic circulation in the Gulf of Lion under wind conditions influenced by the continental orography (FETCH experiment). J Geophys Res 108:8059, doi:10.1029/2001JC000825

> Finlay K, Beisner B, Barnett A (2007) The use of the laser optical plankton counter to measure zooplankton size, abundance, and biomass in small freshwater lakes. Limnol Oceanogr Methods 5:41-49

Gaardsted F, Tande KS, Basedow SL (2010) Measuring copepod abundance in deep-water winter habitats in the NE Norwegian Sea: intercomparison of results from laser optical plankton counter and multinet. Fish Oceanogr 19:480-492

> Gaedke U (1993) Ecosystem analysis based on biomass size distributions: a case study of a plankton community in a large lake. Limnol Oceanogr 38:112-127

> Gaudy R, Pagano M, Lochet F (1990) Zooplankton feeding on seston in the Rhone River plume area (NW Mediterranean Sea) in May 1988. Hydrobiologia 207:241-249

> Gaudy R, Bianchi M, Pagano M, Soto Y (1996) Cross frontal variability in hydrological and biological structures observed in a river plume area (Rhône mouth, NW Mediterranean Sea). Hydrobiologia 324:131-140

Gaudy R, Youssara F, Diaz F, Raimbault P (2003) Biomass, metabolism and nutrition of zooplankton in the Gulf of Lions (NW Mediterranean). Oceanol Acta 26:357-372

> Giannoulaki M, Pyrounaki MM, Liorzou B, Leonori I and others (2011) Habitat suitability modelling for sardine juveniles (Sardina pilchardus) in the Mediterranean Sea. Fish Oceanogr 20:367-382

> Gilabert J (2001) Short-term variability of the planktonic size structure in a Mediterranean coastal lagoon. J Plankton Res 23:219-226

Herman AW, Harvey M (2006) Application of normalized biomass size spectra to laser optical plankton counter net intercomparisons of zooplankton distributions. J Geophys Res 111:C05S05, doi:10.1029/2005JC002948

> Herman AW, Beanlands B, Phillips EF (2004) The next generation of optical plankton counter: the Laser-OPC. J Plankton Res 26:1135-1145

> Irigoien X, Fernandes JA, Grosjean P, Denis K, Albaina A, Santos M (2009) Spring zooplankton distribution in the Bay of Biscay from 1998 to 2006 in relation with anchovy recruitment. J Plankton Res 31:1-17

> Jackson GA, Checkley DM Jr (2011) Particle size distributions in the upper $100 \mathrm{~m}$ water column and their implications for animal feeding in the plankton. Deep-Sea Res I 58:283-297

Jackson GA, Maffione R, Costello DK, Alldredge AL, Logan BE, Dam HG (1997) Particle size spectra between $1 \mu \mathrm{m}$ and $1 \mathrm{~cm}$ at Monterey Bay determined using multiple instruments. Deep-Sea Res I 44:1739-1767

> Jiang S, Dickey TD, Steinberg DK, Madin LP (2007) Temporal variability of zooplankton biomass from ADCP backscatter time series data at the Bermuda Testbed Mooring site. Deep-Sea Res I 54:608-636

Kouwenberg JHM (1994) Copepod distribution in relation to seasonal hydrographics and spatial structure in the north-western Mediterranean (Golfe du Lion). Estuar Coast Shelf Sci 38:69-90

> Labat JP, Gasparini S, Mousseau L, Prieur L, Boutoute M, Mayzaud P (2009) Mesoscale distribution of zooplankton biomass in the northeast Atlantic Ocean determined with an optical plankton counter: relationships with environmental structures. Deep-Sea Res I 56:1742-1756
Lefevre D, Minas HJ, Minas M, Robinson C, Le B, Williams PJ, Woodward EMS (1997) Review of gross community production, primary production, net community production and dark community respiration in the Gulf of Lions. Deep-Sea Res II 44:801-832

Ludwig W, Dumont E, Meybeck M, Heussner S (2009) River discharges of water and nutrients to the Mediterranean and Black Sea: Major drivers for ecosystem changes during past and future decades? Prog Oceanogr 80:199-217

> Matsuno K, Yamaguchi A, Imai I (2012) Biomass size spectra of mesozooplankton in the Chukchi Sea during the summers of 1991/1992 and 2007/2008: an analysis using optical plankton counter data. ICES J Mar Sci 69:1205-1217

Mikkelsen O, Pejrup M (2001) The use of a LISST-100 laser particle sizer for in-situ estimates of floc size, density and settling velocity. Geo-Mar Lett 20:187-195

Millot C (1990) The Gulf of Lions' hydrodynamics. Cont Shelf Res 10:885-894

Möller KO, St. John M, Temming A, Floeter J, Sell AF, Herrmann JP, Möllmann C (2012) Marine snow, zooplankton and thin layers: indications of a trophic link from smallscale sampling with the Video Plankton Recorder. Mar Ecol Prog Ser 468:57-69

Nicolle A, Garreau P, Liorzou B (2009) Modelling for anchovy recruitment studies in the Gulf of Lions (Western Mediterranean Sea). Ocean Dyn 59:953-968

Nikolioudakis N, Isari S, Pitta P, Somarakis S (2012) Diet of sardine Sardina pilchardus: an 'end-to-end' field study. Mar Ecol Prog Ser 453:173-188

> Ohman MD, Powell JR, Picheral M, Jensen DW (2012) Mesozooplankton and particulate matter responses to a deep-water frontal system in the southern California Current System. J Plankton Res 34:815-827

Pagano M, Gaudy R, Thibault D, Lochet F (1993) Vertical migrations and feeding rhythms of mesozooplanktonic organisms in the Rhône River Plume area (North-west Mediterranean Sea). Estuar Coast Shelf Sci 37:251-269

> Palomera I, Olivar MP, Salat J, Sabatés A, Coll M, García A, Morales-Nin B (2007) Small pelagic fish in the NW Mediterranean Sea: an ecological review. Prog Oceanogr 74:377-396

Petrenko AA (2003) Variability of circulation features in the Gulf of Lion NW Mediterranean Sea. Importance of inertial currents. Oceanol Acta 26:323-338

> Petrenko A, Leredde Y, Marsaleix P (2005) Circulation in a stratified and wind-forced Gulf of Lions, NW Mediterranean Sea: in situ and modeling data. Cont Shelf Res $25: 7-27$

Petrik CM, Jackson GA, Checkley DM Jr (2013) Aggregates and their distributions determined from LOPC observations made using an autonomous profiling float. DeepSea Res I 74:64-81

> Picheral M, Guidi L, Stemmann L, Karl DM, Iddaoud G, Gorsky G (2010) The Underwater Vision Profiler 5: an advanced instrument for high spatial resolution studies of particle size spectra and zooplankton. Limnol Oceanogr Methods 8:462-473

> Planque B, Lazure P, Jégou AM (2004) Detecting hydrological landscapes over the Bay of Biscay continental shelf in spring. Clim Res 28:41-52

> Planque B, Bellier E, Lazure P (2007) Modelling potential spawning habitat of sardine (Sardina pilchardus) and anchovy (Engraulis encrasicolus) in the Bay of Biscay. Fish Oceanogr 16:16-30

> Plounevez S, Champalbert G (2000) Diet, feeding behaviour 
and trophic activity of the anchovy (Engraulis encrasicolus L.) in the Gulf of Lions (Mediterranean Sea). Oceanol Acta 23:175-192

Poulet SA, Laabir M, Chaudron Y (1996) Characteristic features of zooplankton in the Bay of Biscay. Sci Mar 60 (Suppl 2):79-95

Powell JR, Ohman MD (2012) Use of glider-class acoustic Doppler profilers for estimating zooplankton biomass. J Plankton Res 34:563-568

> Pujo-Pay M, Conan P, Joux F, Oriol L, Naudin JJ, Cauwet G (2006) Impact of phytoplankton and bacterial production on nutrient and DOM uptake in the Rhône River plume (NW Mediterranean). Mar Ecol Prog Ser 315:43-54

R Development Core Team (2014) R: a language and environment for statistical computing. R Foundation for Statistical Computing, Vienna

Raimbault P, Durrieu de Madron X (2003) Research activities in the Gulf of Lion (NW Mediterranean) within the 1997-2001 PNEC project. Oceanol Acta 26:291-298

Riandey V (2005) Etude de la structure de taille des populations zooplanctoniques dans différents écosystèmes marins. Apports des nouveaux appareils automatisés d'observation. PhD thesis, Université de la Méditerranée, Marseille

Rubio A, Taillandier V, Garreau P (2009) Reconstruction of the Mediterranean northern current variability and associated cross-shelf transport in the Gulf of Lions from satellite-tracked drifters and model outputs. J Mar Syst 78(Suppl):S63-S78

Salas-Berrios F, Valdés-Aguilera J, Landaeta M, Bustos C, Pérez-Vargas A, Balbontín F (2013) Feeding habits and diet overlap of marine fish larvae from the peri-Antarctic Magellan region. Polar Biol 36:1401-1414

Sano M, Maki K, Nishibe Y, Nagata T, Nishida S (2013) Feeding habits of mesopelagic copepods in Sagami Bay: insights from integrative analysis. Prog Oceanogr 110: $11-26$

Schlitzer R (2014) Ocean Data View 4. Available at http:// odv.awi.de

Schultes S, Lopes RM (2009) Laser optical plankton counter and Zooscan intercomparison in tropical and subtropical marine ecosystems. Limnol Oceanogr Methods 7:771-784

Editorial responsibility: Antonio Bode, A Coruña, Spain
Schultes S, Sourisseau M, Le Masson E, Lunven M, Marié L (2013) Influence of physical forcing on mesozooplankton communities at the Ushant tidal front. J Mar Syst 109-110 (Suppl):S191-S202

Schulz J, Peck MA, Barz K, Schmidt JO and others (2012) Spatial and temporal habitat partitioning by zooplankton in the Bornholm Basin (central Baltic Sea). Prog Oceanogr 107:3-30

> Simpson JH (1997) Physical processes in the ROFI regime. J Mar Syst 12:3-15

Sourisseau M, Carlotti F (2006) Spatial distribution of zooplankton size spectra on the French continental shelf of the Bay of Biscay during spring 2000 and 2001. J Geophys Res 111:C05S09, doi: 10.1029/2005JC003063

Tarling GA, Stowasser G, Ward P, Poulton AJ and others (2012) Seasonal trophic structure of the Scotia Sea pelagic ecosystem considered through biomass spectra and stable isotope analysis. Deep-Sea Res II 59-60: 222-236

> Troupin C, Barth A, Sirjacobs D, Ouberdous M and others (2012) Generation of analysis and consistent error fields using the data interpolating variational analysis (DIVA). Ocean Model Online 52-53:90-101

Tugores MP, Giannoulaki M, Iglesias M, Bonanno A and others (2011) Habitat suitability modelling for sardine Sardina pilchardus in a highly diverse ecosystem: the Mediterranean Sea. Mar Ecol Prog Ser 443:181-205

$>$ Williams R, Conway DVP, Hunt HG (1994) The role of copepods in the planktonic ecosystems of mixed and stratified waters of the European shelf seas. Hydrobiologia 292293:521-530

Yanagi T (2000) Coastal oceanography, Kluwer Publishers, Dordrecht

Zarauz L, Irigoien X, Urtizberea A, Gonzalez M (2007) Mapping plankton distribution in the Bay of Biscay during three consecutive spring surveys. Mar Ecol Prog Ser 345:27-39

Zhou M (2006) What determines the slope of a plankton biomass spectrum? J Plankton Res 28:437-448

Zhou M, Tande KS, Zhu Y, Basedow S (2009) Productivity, trophic levels and size spectra of zooplankton in northern Norwegian shelf regions. Deep-Sea Res II 56:1934-1944

Submitted: October 25, 2013; Accepted: March 27, 2014 Proofs received from author(s): June 3, 2014 